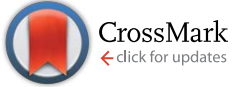

Cite this: RSC Adv., 2016, 6, 64544

\section{Novel synthesised flavone derivatives provide significant insight into the structural features required for enhanced anti-proliferative activity $\dagger$}

\author{
Divyashree Ravishankar, ${ }^{a}$ Kimberly A. Watson, ${ }^{\text {b }}$ Francesca Greco*a \\ and Helen M. I. Osborn*a
}

\begin{abstract}
With many cancers showing resistance to current chemotherapies, the search for novel anti-cancer agents is attracting considerable attention. Natural flavonoids have been identified as useful leads in such programmes. However, since an in-depth understanding of the structural requirements for optimum activity is generally lacking, further research is required before the full potential of flavonoids as antiproliferative agents can be realised. Herein a broad library of 76 methoxy and hydroxy flavones, and their 4-thio analogues, was constructed and their structure-activity relationships for anti-proliferative activity against the breast cancer cell lines MCF-7 (ER +ve), MCF-7/DX (ER +ve, anthracycline resistant) and MDA-MB-231 (ER -ve) were probed. Within this library, 42 compounds were novel, and all compounds were afforded in good yields and $>95 \%$ purity. The most promising lead compounds, specifically the novel hydroxy 4-thioflavones $15 \mathrm{f}$ and $16 \mathrm{f}$, were further evaluated for their anti-proliferative activities against a broader range of cancer cell lines by the National Cancer Institute (NCl), USA and displayed significant growth inhibition profiles (e.g. compound-15f: MCF-7 $\left(\mathrm{Gl}_{50}=0.18 \mu \mathrm{M}\right)$, T-47D $\left(\mathrm{Gl}_{50}=0.03\right.$ $\mu \mathrm{M})$ and MDA-MB-468 $\left(\mathrm{Gl} \mathrm{I}_{50}=0.47 \mu \mathrm{M}\right)$ and compound-16f: MCF-7 $\left(\mathrm{Gl} \mathrm{I}_{50}=1.46 \mu \mathrm{M}\right), \mathrm{T}-47 \mathrm{D}\left(\mathrm{Gl} \mathrm{I}_{50}=\right.$ $1.27 \mu \mathrm{M})$ and MDA-MB-231 $\left.\left(\mathrm{Gl}_{50}=1.81 \mu \mathrm{M}\right)\right)$. Overall, $15 \mathrm{f}$ and $16 \mathrm{f}$ exhibited 7-46 fold greater antiproliferative potency than the natural flavone chrysin (2d). A systematic structure-activity relationship study against the breast cancer cell lines highlighted that free hydroxyl groups and the B-ring phenyl groups were essential for enhanced anti-proliferative activities. Substitution of the $4-\mathrm{C}=\mathrm{O}$ functionality with a $4-\mathrm{C}=\mathrm{S}$ functionality, and incorporation of electron withdrawing groups at $\mathrm{C}-4^{\prime}$ of the $\mathrm{B}$-ring phenyl, also enhanced activity. Molecular docking and mechanistic studies suggest that the antiproliferative effects of flavones $15 \mathrm{f}$ and $16 \mathrm{f}$ are mediated via ER-independent cleavage of PARP and downregulation of GSK-3 $\beta$ for MCF-7 and MCF-7/DX cell lines. For the MDA-MB-231 cell line, restoration of the wild-type p53 DNA binding activity of mutant p53 tumour suppressor gene was indicated.
\end{abstract}

Received 28th April 2016 Accepted 31st May 2016

DOI: 10.1039/c6ra11041j

www.rsc.org/advances as anticancer agents, ${ }^{3-11}$ the success of such approaches has been exemplified through the development of flavone derivatives such as flavopiridol (for chronic lymphocytic leukemia), ${ }^{\mathbf{1 2 - 1 4}}$ silibinin (for prostate cancer), ${ }^{\mathbf{1 5}}$ and quercetin ${ }^{\mathbf{1 6}}$ and its derivative QC12 ${ }^{17}$ (for ovarian cancer), which are at various stages of clinical application. Although the natural flavonoids demonstrate anti-proliferative activities and can themselves act as useful leads, these activities have often been reported at pharmacologically non-achievable high micromolar concentrations (50-100 $\mu \mathrm{M}) .{ }^{18-21}$ Therefore, medicinal chemistry strategies are essential to optimise the pharmacokinetic profiles of these compounds, in order to ensure that the full clinical applications for flavonoids are realised. In this study, we have proposed methylation of hydroxyls, and conversion of 4$\mathrm{C}=\mathrm{O}$ to $4-\mathrm{C}=\mathrm{S}$, as a promising strategy to improve the activities of flavonoids, since these structural motifs could lead to flavonoids with desirable physiochemical properties such as increased lipophilicity and metabolic stability. Therefore, the 
aim of this study was to elucidate the effects of methylation of free hydroxyls and $4-\mathrm{C}=\mathrm{S}$ substitution on the anti-proliferative properties of the flavonoids by undertaking the systematic design, synthesis and biological analysis of a well-defined library of hydroxy flavone analogues. In addition, synthesis of this library of compounds would allow structure-activity relationships (SARs) to be determined. This is of particular importance for flavonoids as in-depth understanding of the SARs for anticancer properties of flavones is still limited. ${ }^{22,23}$ Specifically, the significance of some of their core structural features for activity, such as hydroxyl substitutions at different positions on the flavonoid rings, and the effect of methylation of the free hydroxyls on activity, are poorly defined. Also, the impact of modifying the $4-\mathrm{C}=\mathrm{O}$ substituent on the anticancer activities of flavones has not been extensively studied.

\section{Results and discussion}

\section{Design and synthesis}

To realise the aims of this study, structurally related hydroxy and methoxy flavones, and their 4-thio derivatives, were synthesised. The synthesis of the methoxy and hydroxy flavone scaffolds was achieved using a synthetic strategy involving the Baker-Venkataraman rearrangement as a key step (Scheme 1). ${ }^{\mathbf{2 4 , 2 5}}$ The 4-thio analogues were obtained according to Scheme $2^{26}$ in $20-30 \%$ overall yield (see Experimental section in $\mathrm{ESI} \dagger$ material for full details).

First, the effects of methylation and 4-thio modifications on flavones with different numbers of hydroxyl groups and different positions of hydroxyls on ring-A, were investigated. Thus, 20 flavones comprising of (i) dihydroxy flavones with hydroxyl substitution on ring-A at the C-7,8 or C-5,7 positions, (ii) tetrahydroxy flavones with dihydroxyl substitution on ring-A (at the C-7,8 or C-5,7 positions) and on ring-B (at the C-3' and C$4^{\prime}$ positions), and (iii) pentahydroxy flavones with dihydroxyl substitution on ring-A (at the C-5,7 position only) and on ring-B (at the $\mathrm{C}-3^{\prime}$ and $\mathrm{C}-4^{\prime}$ positions) as well as a hydroxyl group at the

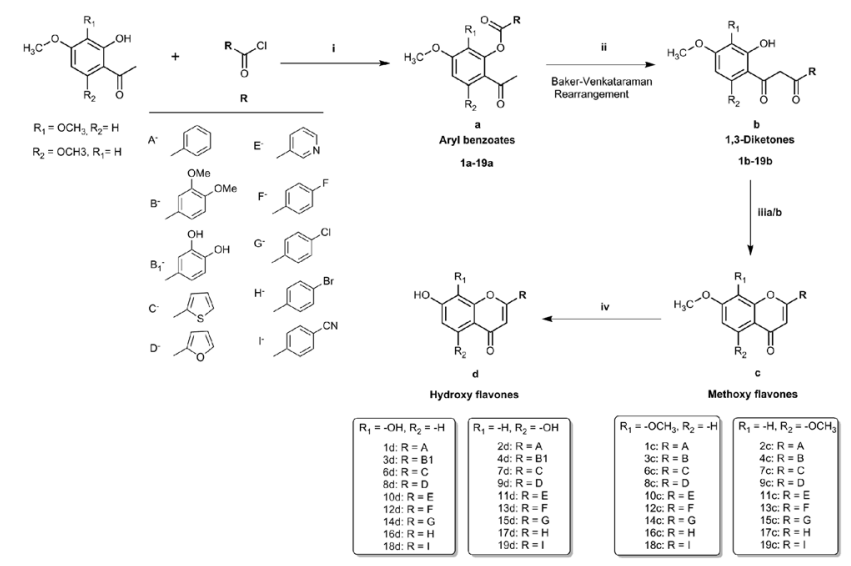

Scheme 1 Synthesis of methoxy flavones and hydroxy flavones (1cd to $19 \mathrm{c}$-d) (i) pyridine, $75^{\circ} \mathrm{C}, 1 \mathrm{~h}$; (ii) pyridine, $\mathrm{KOH}, 50-75^{\circ} \mathrm{C}, 2 \mathrm{~h}$; (iii) (a) glacial acetic acid, $1 \% \mathrm{H}_{2} \mathrm{SO}_{4}, 90-110{ }^{\circ} \mathrm{C}, 1 \mathrm{~h}$, (b) $\mathrm{CHCl}_{3}, 0{ }^{\circ} \mathrm{C}$ to room temperature, $30 \mathrm{~min}$ (iv) dry $\mathrm{DCM}, \mathrm{BBr}_{3}$, room temperature/40 ${ }^{\circ} \mathrm{C}, 4 \mathrm{~h}$ /overnight.

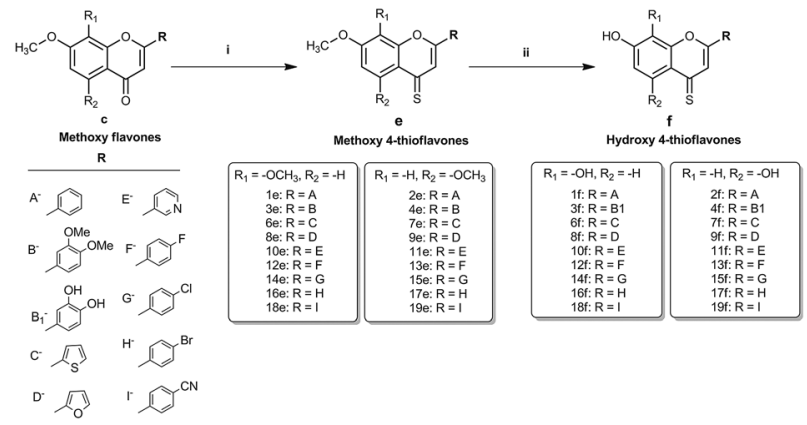

Scheme 2 Synthesis of 4-thiocarbonyl analogues of the hydroxy and methoxy flavones ( $1 \mathrm{e}-\mathrm{f}$ to $19 \mathrm{e}-\mathrm{f}$ ) (i) dry toluene, Lawesson's reagent, $110{ }^{\circ} \mathrm{C}, 4 \mathrm{~h}$ (ii) dry $\mathrm{DCM}, \mathrm{BBr}_{3}$, room temperature $/ 40^{\circ} \mathrm{C}, 4 \mathrm{~h}$ /overnight.

C-3 position on ring-C were designed and synthesised. The analogous methoxy and 4-thio derivatives were also prepared (compounds-1c-f to 5c-f, series-1, Fig. 1).

The pentahydroxy flavone (quercetin) derivatives (5c-f) were obtained starting from pentahydroxy flavone (purchased) according to Scheme $3^{27,28}$ in $36 \%$ overall yield and with $99 \%$ purity by HPLC. This represents an improvement on the recently reported synthesis of $\mathbf{5 f}$, both in terms of overall yield and purity ${ }^{29}$ (22\% overall yield and $95 \%$ purity). The panel of flavones studied herein also contained the well-known natural flavones chrysin (2d), luteolin (4d) and quercetin (5d) to allow comparisons to be made between the novel analogues prepared in our laboratory and some standard flavonoids. The design of further series of flavones was guided by the anti-proliferative activities of series-1 compounds. Therefore, compound-2f, a dihydroxy 4-thio flavone that was identified to possess promising anti-proliferative activity in in vitro screening (discussed below), was considered as a candidate for further optimisation through the bioisostere approach and Topliss scheme. ${ }^{30}$ This resulted in the synthesis of a focused set of dihydroxy flavone analogues (bearing C-7,8 and C-5,7 hydroxyls on ring-A) with phenyl bioisosteres (series-2, Fig. 1), and phenyl groups with electron-withdrawing substituents at the C-4' position (based on the Topliss scheme for the optimisation of

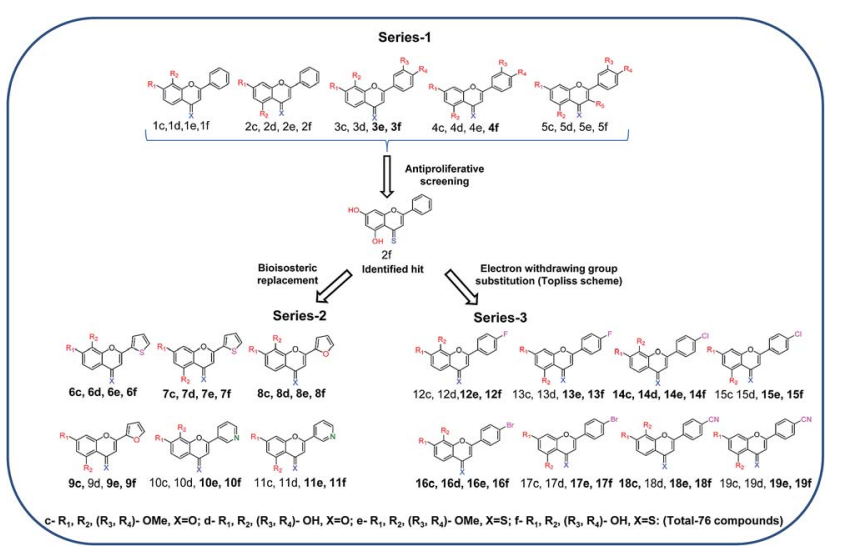

Fig. 1 Library of the synthesised flavone derivatives. Novel compounds are highlighted in bold. 


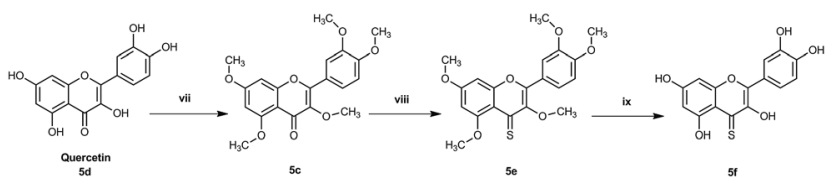

Scheme 3 Synthesis of methoxy and 4-thiocarbonyl analogues of pentahydroxy flavone $(5 \mathrm{c}-\mathrm{f})$ (i) dimethyl sulfate, $15 \% \mathrm{KOH}$, room temperature to $90{ }^{\circ} \mathrm{C}$, overnight (ii) dry toluene, Lawesson's reagent, $110^{\circ} \mathrm{C}, 4 \mathrm{~h}$ (iii) dry $\mathrm{DCM}, \mathrm{BBr}_{3}, 40^{\circ} \mathrm{C}$, overnight.

phenyl ring substitution in drug design ${ }^{30}$ ) (series-3, Fig. 1) as ring-B. The series-2 bioisosteric analogues of $2 \mathrm{f}$ comprised of dihydroxy and dimethoxy flavones, as well as their 4-thioflavone derivatives, with a five-membered 2-thienyl and 2-furanyl group, and a six-membered 3-pyridyl group [compounds $6 \mathbf{c}-\mathbf{f}$ to 11c-f]. Series-3 involved 7,8 and 5,7 dihydroxy, dimethoxy flavones, and their 4-thio flavone analogues with electron-withdrawing groups (EWGs) such as fluoro $(-\mathrm{F})$, chloro $(-\mathrm{Cl})$, bromo $(-\mathrm{Br})$ and cyano $(-\mathrm{CN})$ at the $\mathrm{C}-4^{\prime}$ position of the phenyl ring (ring-B) [compounds 12c-f to $\mathbf{1 9 c - f}$ ]. It is noteworthy that for the synthesis of novel flavones containing nitrogen atoms (e.g. the 3-pyridyl and 4-cyano phenyl groups), during the cyclisation step (step (iii-a)) in the presence of concentrated sulfuric acid in glacial acetic acid, the 1,3-diketone intermediates (compound 10b, 11b and 19b) were found to undergo hydrolysis instead of cyclisation and dehydration, to yield the corresponding methoxy flavones. Therefore, the cyclisation of such 1,3-diketones was instead accomplished in high yields (70-80\%) by the addition of concentrated sulfuric acid into the solution of the 1,3-diketone in $\mathrm{CHCl}_{3}$ at $0{ }^{\circ} \mathrm{C}^{\mathbf{3 1}}$ (step (iii-b)).

Overall, multiple series of flavone derivatives comprising of hydroxy flavones (free $-\mathrm{OH}$ and $4-\mathrm{C}=\mathrm{O}$ ), hydroxy 4-thioflavones (free $-\mathrm{OH}$ and $4-\mathrm{C}=\mathrm{S}$ ), methoxy flavones ( $-\mathrm{OMe}$ and $4-\mathrm{C}=\mathrm{O}$ ) and methoxy 4-thioflavones (-OMe and $4-\mathrm{C}=\mathrm{S}$ ) with different $\mathrm{B}$ ring substitutions were successfully synthesised (summarised in Fig. 1). Out of 76 compounds, 42 compounds (3e, $\mathbf{3 f}, \mathbf{4 f}, \mathbf{6 d - f}$, $7 c-f, 8 c-f, 9 c, 9 e, 9 f, 10 e, 10 f, 11 e, 11 f, 12 e, 12 f, 13 e, 13 f, 14 c-f$, 15e, 15f, 16c-f, 17e, 17f, 18c, 18e, 18f, 19c, 19e and 19f) were prepared and characterised for the first time. All of the synthesised compounds were characterised by ${ }^{1} \mathrm{H}$ and ${ }^{13} \mathrm{C}$ NMR and IR spectroscopy, and high-resolution mass spectrometry. The purity of these compounds was established by reverse phase HPLC and the purities were found to be $>95 \%$ in all cases.

\section{Anti-proliferative evaluation}

As flavonoids have been reported to show activity against breast cancer cell lines, ${ }^{32-34}$ all of the synthesised compounds (1c-f to 19c-f) were evaluated for their anti-proliferative activity against the estrogen-responsive breast cancer cell lines MCF-7, and the clinically relevant anthracycline-resistant MCF-7/DX (which mimics the multi-drug resistant scenario in patients), as well as the estrogen-independent, triple negative breast cancer cell line MDA-MB-231, using the MTT assay. The initial series of compounds (series 1 , i.e. 1c-f to $\mathbf{5 c - f}$ ) was first evaluated against MCF-7 and MCF-7/DX cell lines to investigate the effects of methylation and 4-thio substitution on flavones with differing numbers of hydroxyl groups as well as with different positions on the A-ring. The $\mathrm{IC}_{50}$ values (half maximal inhibitory concentration) of these compounds were determined as a measure of their respective cytotoxicity and these values are tabulated in Table 1. For this series, compound-2f with the dihydroxy groups at the $\mathrm{C}-5,7$ positions on ring-A, and 4-thio substitution, showed the highest anti-proliferative potency with IC $_{50}$ values of $7.1 \pm 0.51 \mu \mathrm{M}$ and $34.93 \pm 5.75 \mu \mathrm{M}$ against MCF-7 and MCF-7/DX cell lines, respectively. Compounds 1f, 3e, 3f, 4d and 5d showed moderate cytotoxicity with $\mathrm{IC}_{50}$ values of $25.6 \pm$ $1.26 \mu \mathrm{M}, 23.5 \pm 4.27 \mu \mathrm{M}$ and $11.8 \pm 1.79 \mu \mathrm{M}$, respectively however, these compounds were weakly anti-proliferative against the MCF-7/DX cell line with $\mathrm{IC}_{50}$ values of $176.3 \pm$ $1.61 \mu \mathrm{M},>250 \mu \mathrm{M}$ and $>250 \mu \mathrm{M}$, respectively. Compounds $1 \mathrm{c}$, 1d, 1e, 9c, 3c, 3d, 4c, 4e, 5c, 5e and $5 f$ were found to be less active against both MCF-7 and MCF-7/DX cell lines with $\mathrm{IC}_{50}$ values $>30 \mu \mathrm{M}$ and $>85 \mu \mathrm{M}$, respectively. The $\mathrm{IC}_{50}$ values for the wellknown natural flavones in this series, 2d (chrysin), 4d (luteolin) and $5 \mathbf{d}$ (quercetin) were found to be $25.6 \pm 1.26 \mu \mathrm{M}, 21.6 \pm$ $0.81 \mu \mathrm{M}$ and $13.7 \pm 0.61 \mu \mathrm{M}$, respectively, against the MCF-7 cell line and the obtained values are in the range of their literature reported values. ${ }^{35,36}$ In general, all compounds exhibited a 3-10 fold lower anti-proliferative activity against MCF-7/DX, which could be because these compounds might act as substrates of the efflux pump P-gp, which is generally over expressed in the MCF-7/DX cell line. ${ }^{37}$

Next, series 1 compounds (1c-f to $\mathbf{5 c - f}$ ) were assessed for their anti-proliferative activities at $10 \mu \mathrm{M}$ concentration against an ER - ve hormone-independent breast cancer cell line, MDAMB-231. The 4-thio derivatives, and in particular the hydroxy compounds, exhibited greater anti-proliferative activity than the methoxy and hydroxy flavone analogues. However, no derivatives reached the $\mathrm{IC}_{50}$ at $10 \mu \mathrm{M}$ (see ESI, Fig. S1†).

As compound-2f was identified as a promising lead compound, further novel analogues of compound-2f were prepared to discover more active flavone derivatives. Thus a series of bioisosteric analogues of the B-ring phenyl group of compound-2f (series-2, compounds $\mathbf{6 c - f}$ to 11c-f), and a series of compound-2f analogues with electron-withdrawing substituents at the $\mathrm{C}^{\prime}$ position (series-3, compounds $12 \mathrm{c}-\mathbf{f}$ to $19 \mathrm{c}-\mathbf{f}$ ), along with their methoxy (both $4-\mathrm{C}=\mathrm{O}$ and $4-\mathrm{C}=\mathrm{S}$ ) and their 7,8-regioisomeric analogues (both $4-\mathrm{C}=\mathrm{O}$ and $4-\mathrm{C}=\mathrm{S}$ ), were synthesised and evaluated for their anti-proliferative activities. Since compound-2f was identified to be active below $10 \mu \mathrm{M}$ and $50 \mu \mathrm{M}$ against MCF-7 and MCF-7/DX, respectively, these subsequently synthesised compounds were initially assessed for their anti-proliferative activities at $10 \mu \mathrm{M}$ concentration against the MCF-7 and MDA-MB-231 cell lines, and at $50 \mu \mathrm{M}$ against the MCF-7/DX cell line. Compounds that reduced the cell viability below $50 \%$ in the initial screening were arbitrarily classified as 'active' and they were then evaluated at a range of concentrations (between 0.1 and $100 \mu \mathrm{M}$ ) against the respective cell line to determine their $\mathrm{IC}_{50}$ values.

In the initial screening, series-2 compounds with bioisosteric replacements showed a decreased/complete loss of activity with cell viability $>50 \%$ (see ESI, Fig. S2 $\dagger$ ). Among series-3, the novel compounds $14 \mathrm{f}$ and $\mathbf{1 6 f}$ were found to be 
Table $1 \quad I C_{50}$ values of the compounds from series $1(1 c-f$ to $5 c-f)$ against the MCF-7 and MCF-7/DX cell lines ${ }^{a}$

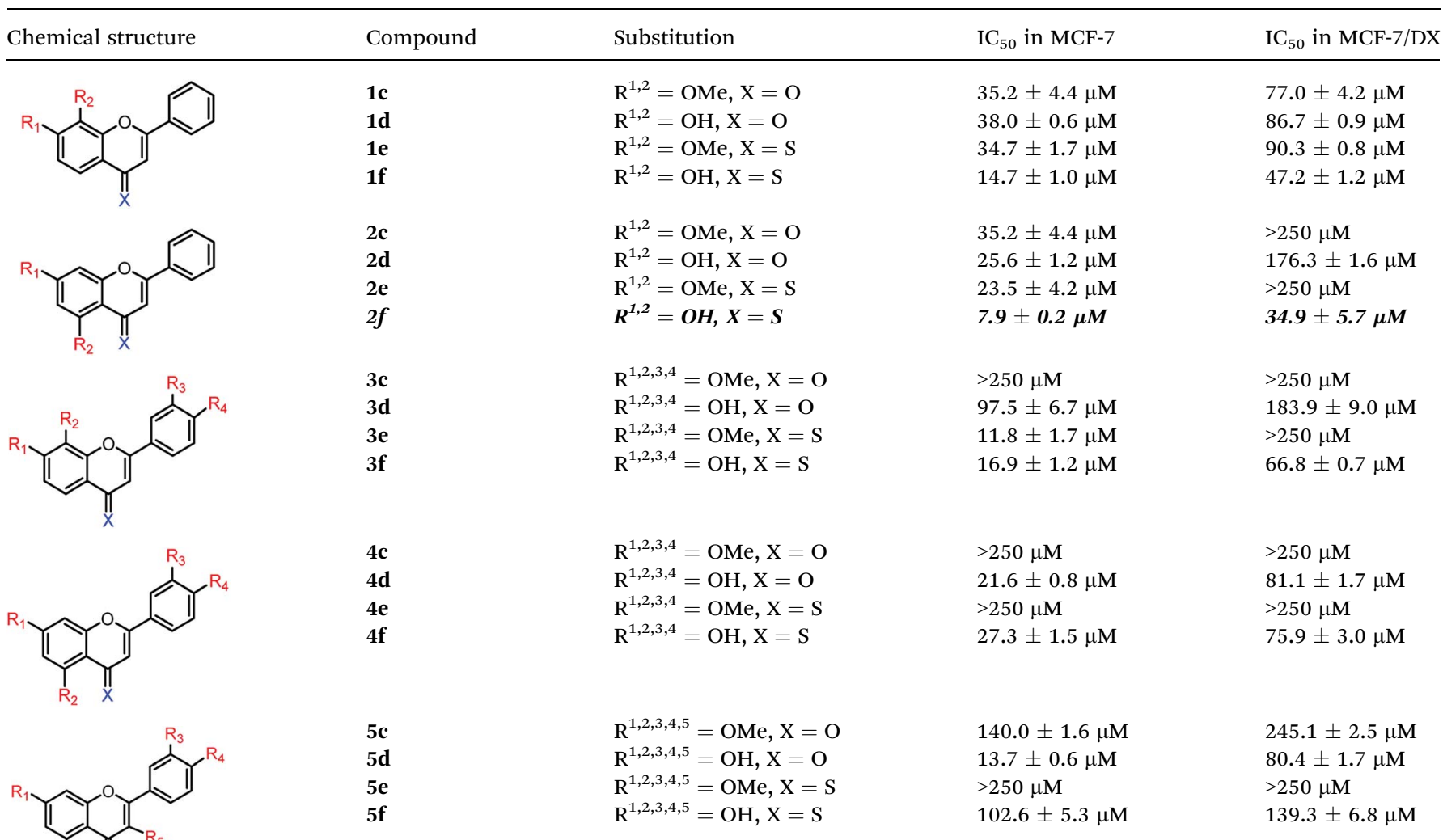

\footnotetext{
${ }^{a}$ Note: most active compound of the series is highlighted in bold.
}

active against all three cell lines, and novel compounds 13f, 15f, 17f and 19f were found to be active against both the MCF-7 and MCF-7/DX cell lines. Novel compounds $\mathbf{1 2 f}$ and $\mathbf{1 8 f}$ were found to be active only against the MCF-7 cell line (Fig. 2). These active compounds were further tested against the respective cell lines at different concentrations ranging from 0.1 to $100 \mu \mathrm{M}$ to determine their $\mathrm{IC}_{50}$ values. The determined $\mathrm{IC}_{50}$ values are listed in Table 2. Among these, novel compounds $\mathbf{1 5 f}\left(\mathrm{IC}_{50}=1.0\right.$ $\pm 0.1 \mu \mathrm{M}$ and $9.1 \pm 0.1 \mu \mathrm{M}$ against MCF-7 and MCF-7/DX cell lines respectively) and $16 f\left(\mathrm{IC}_{50}=4.9 \pm 0.7 \mu \mathrm{M}, 6.5 \pm 0.4 \mu \mathrm{M}\right.$ and $8.9 \pm 0.9 \mu \mathrm{M}$ against MCF-7, MCF-7/DX and MDA-MB-231 cell lines respectively) were identified as active compounds.

Novel insights into structure-activity relationships (SARs). Comparison of the anti-proliferative activities of methoxy flavones (both $4-\mathrm{C}=\mathrm{O}$ and $4-\mathrm{C}=\mathrm{S}$ ) with their corresponding hydroxy flavones illustrates that the methoxy flavones were less anti-proliferative than their hydroxy analogues with the exception of compound-3e [7,8,3', $4^{\prime}$-tetramethoxy 4-thioflavone, $\mathrm{IC}_{50}$ $=11.8 \pm 1.79 \mu \mathrm{M}$ against the MCF-7 cell line]. For example, hydroxy flavone $4 \mathbf{d}$ possesses an $\mathrm{IC}_{50}$ value of $21.6 \pm 0.8 \mu \mathrm{M}$, whereas the $\mathrm{IC}_{50}$ value of its methoxy flavone derivative-4c was found to be $>250 \mu \mathrm{M}$. This highlights that the free hydroxyls are important for anti-proliferative activities (presumably via hydrogen bonding interactions with the potential biological cellular target).
The importance of free hydroxyls for anti-proliferative activity previously has been debated in the literature, with contradicting results. Thus, the results from our programme support findings ${ }^{38,39}$ that indicate that polymethoxylation decreases the anti-proliferative activity, but contradict earlier findings that suggested higher anti-proliferative activities for polymethoxylated flavones against MCF-7, ${ }^{\mathbf{2 0 , 4 0}}$ human leukemic HL-60 ${ }^{41}$ and melanoma cell lines. ${ }^{19}$

Further, from the comparison of anti-proliferative activities between the hydroxy flavones (free $-\mathrm{OH}$ and $4-\mathrm{C}=\mathrm{O}$ ) and their 4-thio analogues (free $-\mathrm{OH}$ and $4-\mathrm{C}=\mathrm{S}$ ), it was apparent that the substitution of $4-\mathrm{C}=\mathrm{S}$ for $4-\mathrm{C}=\mathrm{O}$ enhances the antiproliferative activity [compound-2f (free $-\mathrm{OH}$ and $4-\mathrm{C}=\mathrm{S}$ ), $\mathrm{IC}_{50}$ $=7.9 \pm 0.8 \mu \mathrm{M}<$ compound-2d (free $-\mathrm{OH}$ and $4-\mathrm{C}=\mathrm{O}$ ), $\mathrm{IC}_{50}=$ $25.6 \pm 1.2 \mu \mathrm{M}]$.

(a) Influence of number and position of hydroxyls. By comparing the anti-proliferative activities of flavone derivatives (free $-\mathrm{OH}$ and $4-\mathrm{C}=\mathrm{O}$ ) with different numbers of hydroxy groups, it was observed that the anti-proliferative activities against the MCF-7 cell line were in the order pentahydroxy flavone (5d) $\left[\mathrm{IC}_{50}=13.7 \pm 0.6 \mu \mathrm{M}\right]>$ tetrahydroxy flavone $(\mathbf{4 d})$ $\left[\mathrm{IC}_{50}=21.6 \pm 0.8 \mu \mathrm{M}\right] \approx$ dihydroxy flavone $(2 \mathrm{~d})\left[\mathrm{IC}_{50}=25.6 \pm\right.$ $0.6 \mu \mathrm{M}]$. However, an opposite correlation was observed in the case of the hydroxy 4-thioflavone derivatives (free - $\mathrm{OH}$ and 4$\mathrm{C}=\mathrm{S}$ ), where the order of anti-proliferative activities was found 

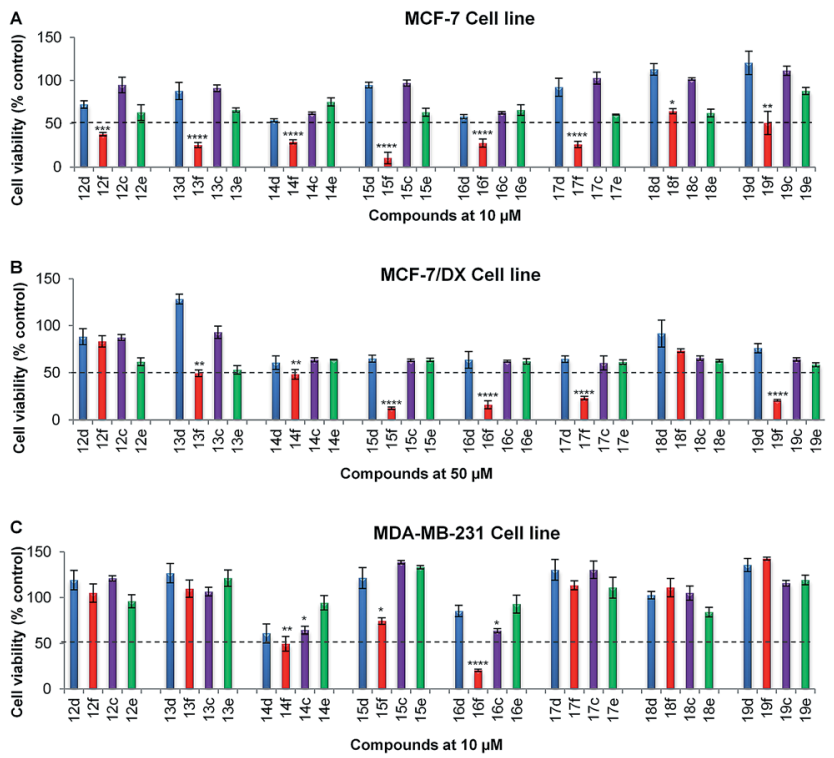

Fig. 2 Anti-proliferative activities of compounds $12 c-f$ to $19 c-f$ against (A) MCF-7 cell line (B) MCF-7/DX cell line (C) MDA-MB-231 cell line. Cell viability was determined using MTT assay in the presence of compounds $12 \mathrm{c}-\mathrm{f}$ to $19 \mathrm{c}-\mathrm{f}$ at $10 \mu \mathrm{M}$ concentration against the MCF-7 cell line and MDA-MB-231 cell lines, and $50 \mu \mathrm{M}$ concentration against the MCF-7/DX cell line. Data are expressed as the mean \pm standard error of the mean (SEM) $(n=3)$. Cells without treatment serve as control. Statistical significance was estimated, with respect to the control, by one-way ANOVA, followed by Bonferroni's post hoc test $(* p<0.05, * * p<0.01, * * * p<0.001$ and $* * * * p<0.0001)$. Dashed line corresponds to $50 \%$ cell viability and those compounds showing $<50 \%$ cell viability were considered as active. Colour coding: blue - hydroxy flavone $(-\mathrm{OH}, 4-\mathrm{C}=\mathrm{O})$, red - hydroxy 4-thioflavone $(-\mathrm{OH}, 4-\mathrm{C}=\mathrm{S})$, purple - methoxy flavone $(-\mathrm{OMe}, 4-\mathrm{C}=\mathrm{O})$ and green - methoxy 4thioflavone $(-\mathrm{OMe}, 4-\mathrm{C}=\mathrm{S})$.

to be dihydroxy 4-thioflavone $(2 \mathrm{f})\left[\mathrm{IC}_{50}=7.9 \pm 0.3 \mu \mathrm{M}\right]>$ tetrahydroxy 4-thioflavone (4f) $\left[\mathrm{IC}_{50}=27.3 \pm 1.5 \mu \mathrm{M}\right] \approx$ pentahydroxy 4-thioflavone $(5 \mathbf{5})\left[\mathrm{IC}_{50}=102.6 \pm 5.4 \mu \mathrm{M}\right]$. This indicates that the number of hydroxyls is not a determining factor for the anti-proliferative activities, in the case of hydroxy flavones (free $-\mathrm{OH}$ and $4-\mathrm{C}=\mathrm{O}$ ). In complete contrast, the number of hydroxyl groups in hydroxy 4-thioflavones plays an important role in their anti-proliferative activities and the dihydroxy 4-thioflavones were found to be the most active flavones.

In terms of the position of the hydroxyls, flavones with 5,7-hydroxyls on the A-ring were more active than their corresponding 7,8-hydroxy flavones. For example, 5,7,3', $4^{\prime}$-tetrahydroxy flavone (4d) $\left[\mathrm{IC}_{50}=21.6 \pm 0.8 \mu \mathrm{M}\right]>7,8,3^{\prime}, 4^{\prime}$-tetrahydroxy flavone (3d) $\left[\mathrm{IC}_{50}=97.5 \pm 6.7 \mu \mathrm{M}\right]$ and 5,7-dihydroxy 4-thioflavone (2f) $\left[\mathrm{IC}_{50}=7.9 \pm 0.2 \mu \mathrm{M}\right]>7,8$-dihydroxy 4-thioflavone (2e) $\left[\mathrm{IC}_{50}=14.7 \pm 1.0 \mu \mathrm{M}\right]$.

(b) Effect of bioisosteric replacements. Replacement of the Bring phenyl group with a bioisostere (e.g. either a fivemembered 2-thienyl, a 2-furanyl group, or a six-membered 3pyridyl group) resulted in a significant loss of anti-proliferative activity. This highlighted that the presence of a phenyl group as ring-B is favourable for anti-proliferative activity. (c) Influence of electron-withdrawing groups. Interestingly, introduction of EWGs at the C-4' position of the phenyl group, mainly with halogens such as $\mathrm{F}$ (12f and 13f), $\mathrm{Cl}$ (14f and 15f) and $\mathrm{Br}$ (16f and 17f) was found to enhance anti-proliferative activities in comparison to the flavones with an unsubstituted phenyl B-ring (compounds $\mathbf{1 f}$ and $\mathbf{2 f}$ ). In particular, the introduction of $\mathrm{Cl}$ and $\mathrm{Br}$ groups increased the anti-proliferative potencies 2-7 fold (14f, 15f, 16f and 17f) against MCF-7 and MCF-7/DX cell lines, and also their introduction afforded 7,8dihydroxy 4-thioflavones with an increased anti-proliferative activity towards MDA-MB-231 cells (compound-1f: cell viability at $10 \mu \mathrm{M}$ was $79 \%$, whereas, compound-14f (containing $-\mathrm{Cl}$ ) and compound-16f (containing - $\mathrm{Br}$ ) showed $49 \%$ and $20 \%$ cell viability at $10 \mu \mathrm{M}$ against MDA-MB-231). The pronounced activity observed for the $-\mathrm{F},-\mathrm{Cl}$ and $-\mathrm{Br}$ substituted 4-thioflavones could be attributed to their increased lipophilicity, as can be observed by the decrease in $\mathrm{IC}_{50}$ values (more active) for increasing theoretical $\log P$ values (Table 2). A summary of SARs for the anti-proliferative activities of flavones analysed herein is depicted in Fig. 3.

Molecular mechanism of action. Next, the probable molecular mechanism of the anti-proliferative activities of the flavonoids was explored. Two plausible molecular mechanisms were postulated. (a) As the majority of flavones evaluated herein exhibited a strong and selective anti-proliferative activity against the estrogen-responsive breast cancer cell line that expresses high levels of estrogen receptor- $\alpha(\mathrm{ER} \alpha),{ }^{42}$ it was anticipated that these compounds may act as estrogen-receptor antagonists by interacting with ER $\alpha$. (b) As these compounds have been reported to interact with cell signalling proteins ${ }^{4,43,44}$ it was hypothesised that these compounds could modulate the cell signalling proteins that are involved in cell survival and cell death.

(a) Interaction with $E R \alpha$. The interaction of flavones 1c-19f with the estrogen receptor- $\alpha(\mathrm{ER} \alpha)$ was first investigated using a molecular docking approach. For this, compounds 1c-19f were docked sequentially into the binding site of the prepared X-ray crystallographic structure of human ER $\alpha$ complexed with an antagonist 2-phenyl-1-[4-(2-piperidin-1-yl-ethoxy)-phenyl]1,2,3,4-tetrahydro-isoquinolin-6-ol [native ligand] (PDB code 1UOM, $2.28 \AA$ resolution $)^{45}$ using a validated docking procedure (see Experimental section). In general, no correlation was observed between the order of anti-proliferative activity and their binding affinities with $\mathrm{ER} \alpha$ (as determined by their respective docking scores). One notable exception was compound-3e which showed higher binding affinity towards the ER $\alpha$ receptor [(docking score of 10.02 , versus the native ligand docking score of 13.0), see ESI (Fig. S3 $\dagger$ ) for details]. This suggests that the majority of the flavonoid derivatives mediate their anti-proliferative effects via estrogen-independent mechanisms. A similar observation has been reported for 5-aminoflavones, which showed remarkable anti-proliferative activity against the ER +ve MCF-7 cell line without ER competition, as determined by the ER binding assay. ${ }^{46}$

To confirm this finding, an ER $\alpha$ antagonism assay was carried out using the human estrogen receptor alpha assay kit which 
Table $2 \quad I C_{50}$ values of the compounds $12 \mathrm{f}$ to $19 \mathrm{f}$ against the MCF-7, MCF-7/DX and MDA-MB-231 cell lines and their correlation with theoretical $\log P$ values $^{a}$

\begin{tabular}{|c|c|c|c|c|c|}
\hline $14 f$ & & 3.40 & $7.9 \pm 2.4 \mu \mathrm{M}$ & $34.0 \pm 4.6 \mu \mathrm{M}$ & $10.9 \pm 2.4 \mu \mathrm{M}$ \\
\hline $19 f$ & & 2.87 & $8.9 \pm 0.6 \mu \mathrm{M}$ & $27.3 \pm 1.8 \mu \mathrm{M}$ & $>10 \mu \mathrm{M}$ \\
\hline $13 f$ & & 3.00 & $5.9 \pm 0.7 \mu \mathrm{M}$ & $41.3 \pm 1.5 \mu \mathrm{M}$ & $>10 \mu \mathrm{M}$ \\
\hline $17 f$ & & 3.67 & $2.5 \pm 0.1 \mu \mathrm{M}$ & $15.4 \pm 0.8 \mu \mathrm{M}$ & $>10 \mu \mathrm{M}$ \\
\hline
\end{tabular}

${ }^{a}$ Note: most active compounds of the series are highlighted in bold. Data represented is mean $\pm \mathrm{SEM}, n=3$. $\log P$ values were determined using ChemDraw ultra 12.1 software.

consists of $\mathrm{ER} \alpha$ reporter cells in which an ER $\alpha$-responsive promoter is functionally linked to the luciferase reporter gene, and allows quantification of changes in the ER $\alpha$ activity via

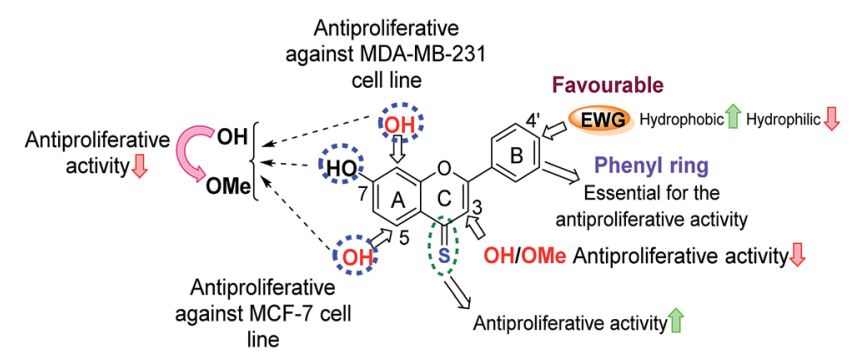

Fig. 3 Summary of the SARs for the anti-proliferative activities of flavones analysed herein. measurement of the changes in luciferase expression. In order to evaluate whether the flavone derivatives mediate their antiproliferative effects via antagonism of $\mathrm{ER} \alpha$, compound-15f $\left(\mathrm{IC}_{50}=1 \mu \mathrm{M}\right)$ compound-16f $\left(\mathrm{IC}_{50}=4.9 \mu \mathrm{M}\right)$ and compound-3e $\left(\mathrm{IC}_{50}=11.8 \pm 1.79 \mu \mathrm{M}\right)$, that were potent against MCF-7 cells, were assessed for their antagonist activity at four-point concentrations $(10-0.1 \mu \mathrm{M})$ in the presence of a constant concentration of $17 \beta$-estradiol ( $3.2 \mathrm{nM}, \mathrm{EC}_{75}$ ). The known antagonist fulvestrant was used as a positive control. Compounds $\mathbf{1 5 f}$ and $\mathbf{1 6 f}$ did not show any decrease in the luciferase activity (induced by $17 \beta$ estradiol), which was in contrast to fulvestrant. However, compound-3e showed a dose-dependent decrease in the luciferase activity [see ESI (Fig. S4†) for details]. These results support the findings from the in silico study that the majority of these 

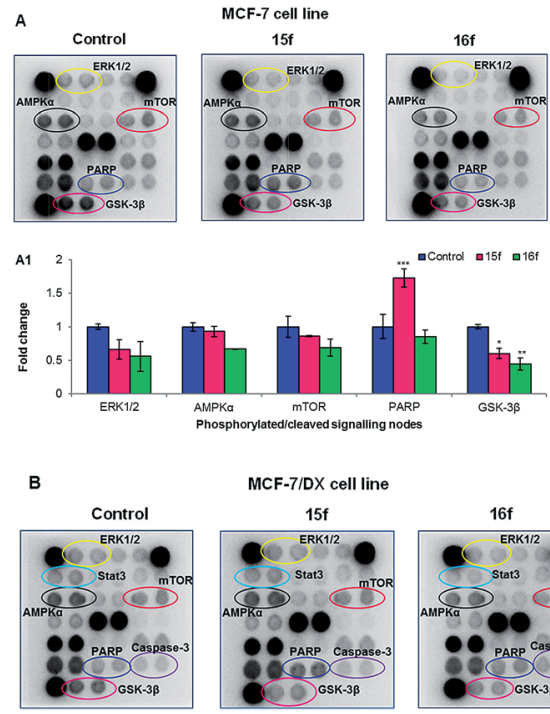

MCF-7/DX cell line
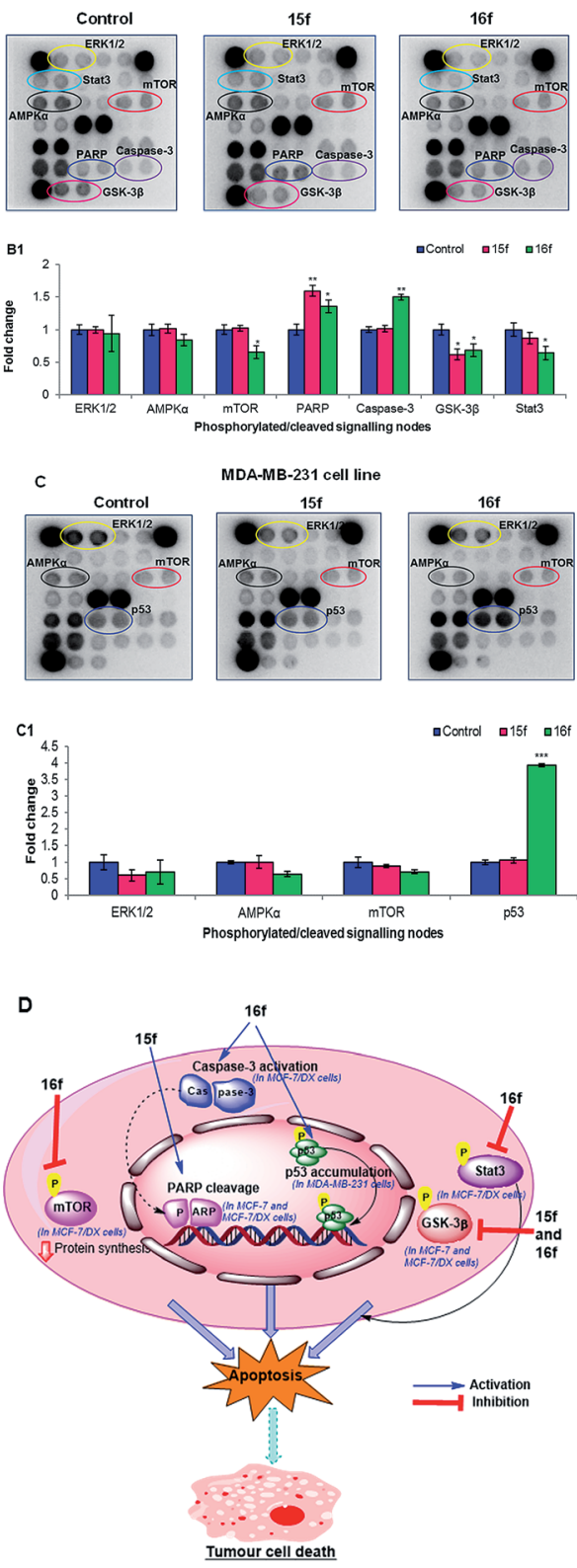

Fig. 4 Chemiluminescent array images of the PathScan Intracellular Signalling array kit revealing various phosphorylated/cleaved signalling nodes in (A) MCF-7 cells, (B) MCF-7/DX cells and (C) MDA-MB-231 cells after the treatment with compounds $15 \mathrm{f}$ and $16 \mathrm{f}$ at $10 \mu \mathrm{M}$ for $24 \mathrm{~h}$. Cells without treatment serve as control. Bar chart representing the fold change in the integrated density of phosphorylated/cleaved signalling nodes in the array image of (A1) MCF-7 cells, (B1) MCF-7/DX compounds (except compound-3e) most likely act through an estrogen-independent mechanism.

(b) Interactions with cell signalling proteins. Next, the signals mediated by compounds $15 f$ and $16 f$ in ER +ve MCF-7 and MCF7/DX cells and ER - ve MDA-MB-231 cells were examined using the PathScan ${ }^{\circledR}$ Intracellular Signalling Array Kit, which allows simultaneous detection of 18 significant and well-characterised signalling molecules that undergo covalent post-translational modifications, such as phosphorylation and proteolysis (cleavage). Protein samples obtained from the treatment of MCF-7, MCF-7/DX and MDA-MB-231 cells with compounds $\mathbf{1 5 f}$ $\left(\mathrm{IC}_{50}<10 \mu \mathrm{M}\right.$ against MCF-7 and MCF-7/DX) and 16f $\left(\mathrm{IC}_{50}<10\right.$ $\mu \mathrm{M}$ against MCF-7, MCF-7/DX and MDA-MB-231 cells) were analysed (Fig. 4). The results showed that the anti-proliferative effects were mediated by significant inhibition of the Akt associated downstream target GSK-3 $\beta$, which is a key signalling molecule for cell survival and proliferation. In addition, compound-15f, which showed greater potency towards MCF-7 cells $\left(\mathrm{IC}_{50}=1 \mu \mathrm{M}\right.$ for $\mathbf{1 5 f} v s$. $\mathrm{IC}_{50}=4.9 \mu \mathrm{M}$ for $\left.\mathbf{1 6 f}\right)$, was found to trigger cell death through PARP cleavage, which is a hallmark of the cell death pathway. ${ }^{47}$ This explains the greater potency of compound-15f towards MCF-7 cells. It is noteworthy that no caspase-3 cleavage was observed; this suggests that the observed PARP cleavage is caspase- 3 independent and the activation of PARP cleavage in MCF-7 cells might have been executed via other caspases such as caspases-6/9. ${ }^{48}$ In the case of MCF-7/DX cells, compound-16f, that has greater activity towards MCF-7/DX cells than compound-15f, mediated its antiproliferative effects through a significant reduction in the phosphorylation of several cell survival proteins such as mTOR, GSK-3 $\beta$ and Stat3, along with induction of cell death through caspase-3 and PARP cleavage. However, compound-15f was found to elicit its anti-proliferative effects through a reduction in the phosphorylation of GSK-3 $\beta$ as well as through induction of cell death via PARP cleavage. Thus, the higher potency of compound-16f could be related to its ability to downregulate multiple cell survival proteins (mTOR, GSK-3 $\beta$ and Stat 3 ) along with its ability to induce cell death via caspase- 3 and PARP cleavage.

Interestingly, treatment of MDA-MB-231 cells with compound-16f showed a 2-fold increase in the levels of p53 compared to the control. MDA-MB-231 cells have a mutant p53 gene $^{\mathbf{4 9 , 5 0}}$ that is more stable and oncogenic unlike the wild type p53 in MCF-7 cells. ${ }^{51}$ The presence of mutant p53 drives the invasiveness of the tumour. ${ }^{52,53}$ However, the increase in the serine-15 phosphorylated p53 (mutant) in compound-16f treated MDA-MB-231 cells [than the control (untreated)] linked with its profound activity suggest that compound-16f induces Ser-15 phosphorylation of a mutant p53 in MDA-MB-231 cells,

cells and (C1) MDA-MB-231 cells after the treatment with and without compounds $15 \mathrm{f}$ and $16 \mathrm{f}$ at $10 \mu \mathrm{M}$ for $24 \mathrm{~h}$. Data are expressed as the mean \pm standard error of the mean (SEM) $(n=4)$. Statistical significance was estimated with respect to the control by one-way ANOVA, followed by Bonferroni's post hoc test $(* p<0.05$, ** $p<0.01$ and $* * * p<$ 0.001). (D) Molecular mechanism of action of $15 \mathrm{f}$ and $16 \mathrm{f}$ in MCF-7, MCF-7/DX and MDA-MB-231 cell lines. 

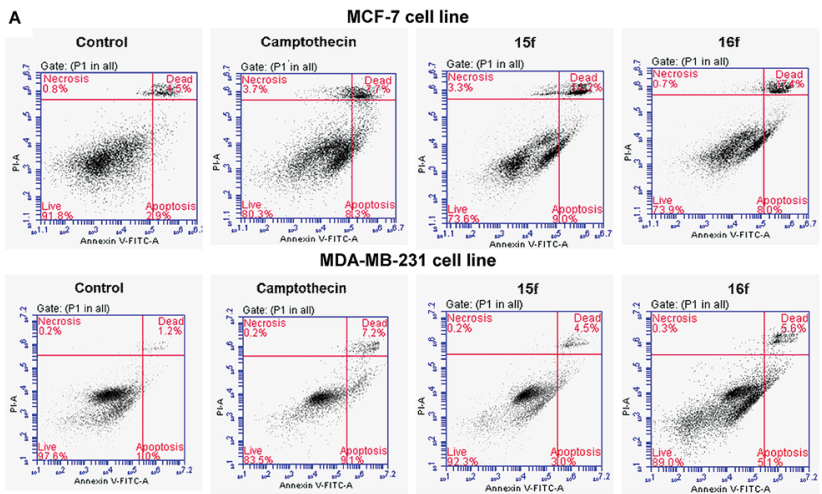

MDA

B
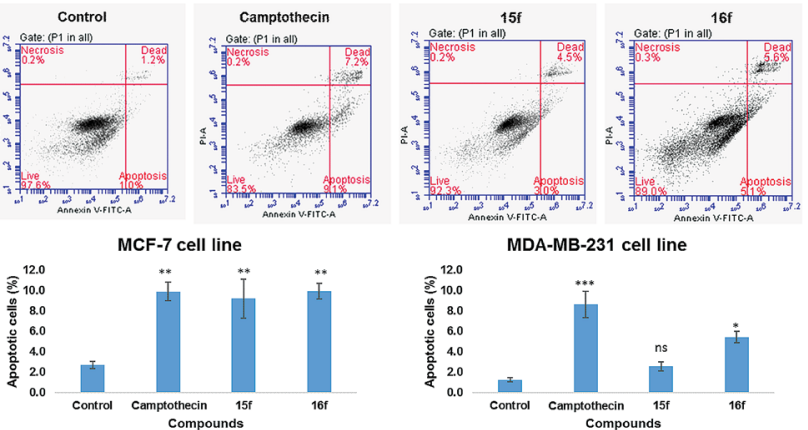

MDA-MB-231 cell line

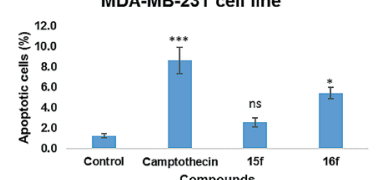

Fig. 5 Apoptosis detection in MCF-7 and MDA-MB-231 cells by flow cytometry. MCF-7 cells were treated with compounds $15 \mathrm{f}$ and $16 \mathrm{f}$ at 1 $\mu \mathrm{M}$ and $5 \mu \mathrm{M}$ respectively for $24 \mathrm{~h}$ and MDA-MB-231 cells were treated with compounds $15 f$ and $16 \mathrm{f}$ at $10 \mu \mathrm{M}$ and $9 \mu \mathrm{M}$ respectively for $24 \mathrm{~h}$. The quadrants were set based on the population of healthy, unstained cells in untreated samples (control) compared to cells treated with 5 $\mu \mathrm{M}$ camptothecin for $24 \mathrm{~h}$. (A) Representative figures showing population of unstained live (annexin $\mathrm{V}-\mathrm{PI}-$, lower left), apoptotic (annexin $\mathrm{V}+\mathrm{PI}-$, lower right), dead (annexin $\mathrm{V}+\mathrm{PI}+$, upper right) and necrotic (annexin $\mathrm{V}-\mathrm{PI}+$, upper left) cells. (B) Bar chart represent the quantification of the apoptotic cells induced upon the treatment of MCF-7 and MDA-MB-231 cells with compounds $15 \mathrm{f}$ and $16 \mathrm{f}$. Data are expressed as mean \pm standard error of the mean (SEM), $n=3$. Statistical significance was estimated with respect to the control (untreated sample) by one-way ANOVA, followed by Bonferroni's post hoc test (ns = nonsignificant; $* p<0.05, * * p<0.01, * * * p<0.001, * * * * p$ $<0.0001)$.

which probably leads to the restoration of wild-type p53 DNA binding activity and induction of cell death. A similar observation has been reported for resveratrol (a chalcone) wherein cell death was induced by restoring the wild-type p53 DNA binding activity via the phosphorylation of a mutant p53 at serine-15 in prostate cancer DU145 cells. ${ }^{54-56}$ This might explain the higher activity of compound-16f against MDA-MB-231 cells $\left(\mathrm{IC}_{50}=8.9\right.$ $\mu \mathrm{M}$ for $\mathbf{1 6 f} v s$. $\mathrm{IC}_{50}>10 \mu \mathrm{M}$ for $\mathbf{1 5 f}$ ).

Overall, these results correlate well with the in vitro findings, and suggest that for the MCF-7 and MCF-7/DX cell lines, the anti-proliferative effects are mediated via ER-independent cleavage of PARP and downregulation of GSK-3 $\beta$. For the MDA-MB-231 cell line, activity could be due to restoration of the wild-type p53 DNA binding activity of the mutant p53 tumour suppressor gene.

Apoptosis determination. As compounds $15 f$ and $16 f$ were found to act via induction of the apoptotic signalling pathway (PARP, caspase-3 and p53), these compounds were further assessed for their ability to induce apoptosis. For this, MCF-7 and MDA-MB-231 cells were treated (at their $\mathrm{IC}_{50}$ concentration for $24 \mathrm{~h})$ with compounds $15 \mathrm{f}(1 \mu \mathrm{M}$ and $10 \mu \mathrm{M}$ against MCF-7 and MDA-MB-231, respectively) or $16 f(5 \mu \mathrm{M}$ and $9 \mu \mathrm{M}$ against MCF-7 and MDA-MB-231, respectively) and were
Table $3 \mathrm{Gl}_{50}$ values for $15 f$ and $16 f$ against 60 cell lines obtained from $\mathrm{NCl} / \mathrm{DTP}$ screening ${ }^{a}$

\begin{tabular}{lll}
\hline & $\mathrm{GI}_{50}(\mu \mathrm{M})$ & \\
\cline { 3 - 3 } Panel/cell line & $\mathbf{1 5 f}$ & $\mathbf{1 6 f}$ \\
\hline Leukaemia & & \\
CCRF-CEM & 4.13 & 2.53 \\
HL-60 & 2.99 & 1.66 \\
K-562 & 3.39 & 2.47 \\
MOLT-4 & 3.93 & 2.16 \\
RPMI-8226 & 2.95 & 1.32 \\
SR & 3.97 & 2.54 \\
& & \\
Non-small cell lung cancer & & 3.26 \\
A549/ATCC & 9.20 & 17.9 \\
EKVX & 17.3 & 1.50 \\
HOP-62 & 1.95 & 1.69 \\
HOP-92 & 1.76 & 7.22 \\
NCI-H226 & 14.6 & 1.52 \\
NCI-H23 & 1.95 & 1.89 \\
NCI-H322M & 2.23 & $\mathbf{0 . 9 7}$ \\
NCI-H460 & 3.09 & 1.16 \\
NCI-H522 & 2.57 &
\end{tabular}

Colon cancer

COLO 205

HCC-2998

HCT-116

HCT-15

HT29

KM12

SW-620

16.8

1.74

2.78

0.48

19.4

2.17

3.85

.53

2.47

2.16

1.32

.54

CNS cancer

SF-268

SF-295

SF-539

SNB-19

SNB-75

U251

Melanoma

LOX IMVI

MALME-3M

M14

MDA-MB-435

SK-MEL-2

SK-MEL-28

SK-MEL-5

UACC-257

UACC-62

Ovarian cancer

IGROV1

3.27

2.09

OVCAR-3

OVCAR-4

OVCAR-5

OVCAR-8

NCI/ADR-RES

SK-OV-3

Renal cancer

ACHN 
Table 3 (Contd.)

\begin{tabular}{lll}
\hline & $\mathrm{GI}_{50}(\mu \mathrm{M})$ & \\
\cline { 2 - 3 } Panel/cell line & $\mathbf{1 5 f}$ & $\mathbf{1 6 f}$ \\
\hline CAKI-1 & 3.12 & 2.65 \\
RXF393 & 4.22 & 2.51 \\
SN12C & 2.83 & 2.61 \\
TK-10 & 4.60 & 4.16 \\
UO-31 & 1.28 & 1.02 \\
& & \\
Prostate cancer & & \\
PC-3 & 3.21 & 2.92 \\
DU-145 & 4.26 & 2.67 \\
& & \\
Breast cancer & & 1.46 \\
MCF-7 & $\mathbf{0 . 1 8}$ & 1.81 \\
MDA-MB-231/ATCC & 2.20 & 6.69 \\
HS 578T & 5.26 & 2.19 \\
BT-549 & 3.40 & 1.27 \\
T-47D & $\mathbf{0 . 0 3}$ & 2.08 \\
MDA-MB-468 & $\mathbf{0 . 4 7}$ &
\end{tabular}

${ }^{a}$ Note: sub-micromolar range $\mathrm{GI}_{50}$ values are highlighted in bold.

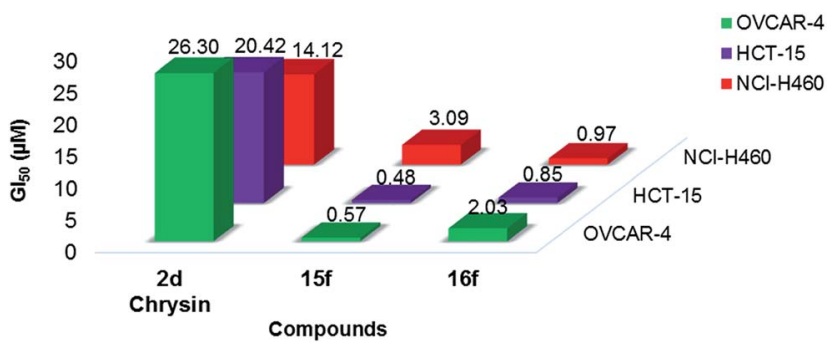

Fig. 6 Comparison of $\mathrm{Gl}_{50}$ values of compounds $15 \mathrm{f}$ and $16 \mathrm{f}$ with $2 \mathrm{~d}$ (chrysin, a well-known natural flavone). Data for $2 d$ (chrysin) were obtained from NCl/DTP screening: December 2010 (NSC407436).

analysed for phosphatidylserine externalization (apoptosis marker) ${ }^{57,58}$ using an annexin V-FITC/propidium iodide (PI) apoptosis detection assay and flow cytometry. As shown in Fig. 5, a significant increase in the percentage of apoptotic cells in comparison to the untreated control was observed in the MCF-7 cells treated with either $\mathbf{1 5 f}$ or 16f, and in the MDA-MB231 cells treated with $\mathbf{1 6 f}$. These results clearly indicate that the flavones $\mathbf{1 5 f}$ and $\mathbf{1 6 f}$ potentially induce apoptosis in the MCF-7 and MDA-MB-231 cells, whilst only $\mathbf{1 6 f}$ potentially induces apoptosis in MDA-MB-231 cells. These observations are in line with the cytotoxicity data/protein array data. Therefore, from the molecular mechanism of action studies, and the apoptotic assay, for compounds $\mathbf{1 5 f}$ and $\mathbf{1 6 f}$ it can be concluded that these compounds induce apoptotic cell death via PARP cleavage in MCF-7 cells, and 16f triggers apoptosis by p53 induction in the MDA-MB-231 cell line.

NCI 60 cell line screening. Finally, to further probe the promising and significant anti-proliferative activities of the novel flavonoids $\mathbf{1 5 f}$ and $\mathbf{1 6 f}$, these compounds were screened for in vitro cytotoxicity by the National Cancer Institute
Developmental Therapeutic Program, ${ }^{59}$ USA (NCI/DTP, USA). Initial evaluation was performed at a single dose of $10 \mu \mathrm{M}$ against 60 different human tumour cell lines using the sulforhodamine B cytotoxic assay. ${ }^{60}$ Both compounds showed potential growth inhibition against a wide range of cancer cell lines (see ESI $\dagger$ ). As a result, these compounds were selected for further 5-dose assay screening against the 60 cell lines (0.01-100 $\mu \mathrm{M}$ ). Three end points, specifically the $\mathrm{GI}_{50}$ (concentration that causes 50\% growth inhibition), TGI (total growth inhibition) and $\mathrm{LC}_{50}$ (the concentration of the drug at which the original cell number is reduced by $50 \%$ ) were determined. The mean inhibitory doses (MID) against 60 cell lines for compound-15f and compound-16f were $2.81 \mu \mathrm{M}$ and $2.39 \mu \mathrm{M}$ respectively. The $\mathrm{GI}_{50}$ values determined for these two compounds against 60 cell lines are presented in Table 3. Interestingly, both compounds 15f and 16f exhibited nanomolar range activity various cell lines. Specifically, compound-15f showed the highest cytotoxicity against the breast cancer cell lines MCF-7 $\left(\mathrm{GI}_{50}=0.18 \mu \mathrm{M}\right)$, T-47D $\left(\mathrm{GI}_{50}=0.03 \mu \mathrm{M}\right)$ and MDA-MB-468 $\left(\mathrm{GI}_{50}=0.47 \mu \mathrm{M}\right)$, HCT-15 (colon cancer, $\mathrm{GI}_{50}=0.48 \mu \mathrm{M}$ ), OVCAR-4 (ovarian, $\mathrm{GI}_{50}$ $=0.57 \mu \mathrm{M}$ ). Also, compound-16f, showed significant cytotoxicity against NCI-H460 (NSCLC, $\mathrm{GI}_{50}=0.97 \mu \mathrm{M}$ ) and HCT-15 (colon cancer, $\left.\mathrm{GI}_{50}=0.85 \mu \mathrm{M}\right)$. The cytotoxicity profile of the wellknown flavone chrysin (2d) [NSC407436] was retrieved from the NCI database (mean dose graph provided in ESI $\dagger$ ) for comparison. Overall, compounds-15f and $\mathbf{1 6 f}$ were found to be 7-8 fold more potent than chrysin (MID-20.10 $\mu \mathrm{M}$, against 51 cell lines). In particular, compounds-15f and $\mathbf{1 6 f}$ were found to be 46 fold and 13 fold more active than chrysin against an ovarian OVCAR-4 cell line, 43 fold and 24 fold more active than chrysin against colon HCT-15 and 5 fold and 15 fold more active than chrysin against the NSCLC NCI-H460 cell line, respectively (Fig. 6).

\section{Conclusions}

A library of 76 compounds containing structurally related methoxy and hydroxy flavones, and their 4-thio analogues, has been designed, synthesised and evaluated for anti-proliferative activity against the breast cancer cell lines MCF-7 (ER +ve), MCF7/DX (ER +ve, anthracycline resistant) and MDA-MB-231 (ER -ve). Within this library, 42 compounds were prepared and characterised for the first time within our laboratory. The study provided significant insight into the structural features required for enhancing the anti-proliferative profiles of flavones, and identified two novel hydroxy 4-thioflavones $\mathbf{1 5 f}$ and 16f, as lead anti-proliferative agents $\left(\mathbf{1 5 f}\left(\mathrm{IC}_{50}=1.0 \pm 0.1\right.\right.$ $\mu \mathrm{M}$ and $9 \pm 0.1 \mu \mathrm{M}$ against MCF-7 and MCF-7/DX cell lines, respectively) and $\mathbf{1 6 f}\left(\mathrm{IC}_{50}=4.9 \pm 0.7 \mu \mathrm{M}, 6.5 \pm 0.4 \mu \mathrm{M}\right.$ and 8.9 $\pm 0.8 \mu \mathrm{M}$ against MCF-7, MCF-7/DX and MDA-MB-231 cell lines, respectively)). A systematic SAR study highlighted the presence of free hydroxyl groups, and the B-ring phenyl groups, as essential for enhanced anti-proliferative activities. Replacement of the $4-\mathrm{C}=\mathrm{O}$ functional group with the $4-\mathrm{C}=\mathrm{S}$ functional group also enhanced the anti-proliferative activities. Incorporation of lipophilic electron withdrawing groups at $\mathrm{C}-4^{\prime}$ of the $\mathrm{B}-$ ring phenyl was found to be favourable, and the increased 
lipophilicity correlates well with the greater anti-proliferative activities. Molecular mechanistic studies have suggested that the anti-proliferative effects of flavones $\mathbf{1 5 f}$ and $\mathbf{1 6 f}$ are mediated via ER-independent cleavage of PARP and downregulation of GSK-3 $\beta$ in the case of MCF-7 and MCF-7/DX cell lines. For the MDA-MB-231 cell line, a probable restoration of the wild-type p53 DNA binding activity of mutant p53 tumour suppressor gene was indicated. Taken together, these results demonstrate that the novel thioflavones $\mathbf{1 5 f}$ and $\mathbf{1 6 f}$ offer considerable potential as anti-proliferative agents within medicinal chemistry programmes focussed on cancer. In addition, the SARs derived herein are likely to contribute significantly to the design and synthesis of novel thioflavones for further therapeutic applications.

\section{Experimental}

\section{Materials and methods}

Cell line and culture. MCF-7 (ER +ve breast cancer cell line) was provided by Tenovus Centre for Cancer Research (Cardiff, UK), MCF-7/DX (a doxorubicin resistant phenotype of MCF-7) was obtained as a gift from Professor Luigi Quintieri from the University of Padova, Italy and MDA-MB-231 (ER -ve breast cancer cell line) were purchased as a frozen stock from the European Collection of Cell Cultures (ECACC). MCF-7 and MCF7/DX cells were cultured in RPMI 1640 supplemented with 5\% fetal bovine serum, MDA-MB-231 cells were cultured in DMEM supplemented with $10 \%$ fetal bovine serum. All of the cell culture reagents were obtained from Lonza, UK. The PathScan Intracellular Signalling array kit was purchased from Cell Signaling (Catalog number-7323). ER $\alpha$ receptor antagonist kit was purchased from Indigo biosciences, USA. Annexin $\mathrm{V} /$ propidium iodide apoptosis detection kit I was procured from BD, Pharmingen ${ }^{\mathrm{TM}}$, UK. For the cell culture experiments, the stock solutions of the test compounds $\left(10 \mathrm{mg} \mathrm{mL} \mathrm{mL}^{-1}\right)$ were prepared in sterile DMSO and ethanol $(1: 1 \mathrm{v} / \mathrm{v})$ and these stocks were then appropriately diluted with the complete culture medium and, the ethanol and DMSO levels were maintained below $1 \%$ in the test concentrations. The $\mathrm{IC}_{50}$ values were calculated using MS excel 2010. Molecular docking was performed using SYBYL-X-2.1 software.

Synthesis. See the ESI. $\dagger$

Anti-proliferative assay. Anti-proliferative activities of the compounds were assessed using the MTT assay at $72 \mathrm{~h}$ of treatment. For this, MCF-7 and MCF-7/DX cells were seeded at a density of $4 \times 10^{4}$ cells per $\mathrm{mL}$ and MDA-MB-231 cells were seeded at a density of $2 \times 10^{4}$ cells per mL into 96 well plates and incubated for $24 \mathrm{~h}$ to allow attachment. After $24 \mathrm{~h}$, the cells were treated with these synthesised derivatives at a range of concentrations ( 0 to $250 \mu \mathrm{M})$ or at single doses $(10 \mu \mathrm{M}$ against MCF-7 and MDA-MB-231 cells, and $50 \mu \mathrm{M}$ against MCF-7/DX cells) for $67 \mathrm{~h}$. After $67 \mathrm{~h}$, MTT assay ${ }^{61}$ was carried out by the addition of $20 \mu \mathrm{L}$ of MTT ( $5 \mathrm{mg} \mathrm{mL}^{-1}$ ) solution in PBS into each well and the cells were incubated for $5 \mathrm{~h}$. The purple crystals formed were dissolved in $100 \mu \mathrm{L}$ of DMSO and the plates were read at $570 \mathrm{~nm}$ using a SPECTRA max UV spectrometer (BioRad). The data represented are the mean of the three individual experiments. The cell viability of the control is considered to be $100 \%$.

$\mathrm{IC}_{50}$ values presented here correspond to the concentration $(T / C) \times 100=50$, where $T=$ absorbance of the test well after 72 $\mathrm{h}$ exposure to the test compound, $C=$ absorbance of control well after $72 \mathrm{~h}$.

$\mathrm{GI}_{50}$ values presented here involve a correction for the cell count at time zero. Therefore the $\mathrm{GI}_{50}$ value for a test drug corresponds to the concentration $\left[\left(T-T_{0}\right) /\left(C-T_{0}\right)\right] \times 100=50$, where $T=$ absorbance of the test well after $48 \mathrm{~h}$ exposure to the test compound, $C=$ absorbance of control after $48 \mathrm{~h}$ and $T_{0}=$ absorbance at time zero.

\section{Molecular docking}

Docking validation. To validate the accuracy of the docking procedure to be used, the original ligands were extracted from the coordinate files (taken from the Protein Data Bank PDB), and then docked again into the corresponding crystal structure of the proteins, using the automated docking procedure in the program Surflex-Dock (SFXC), ${ }^{62,63}$ as provided by SYBYL-X-2.1. The resulting ligand conformation from the docking procedure was compared with the ligand conformation as found in the actual crystal structure of the complex. Comparative structural orientation of the ligand was calculated as the root mean square deviation (RSMD) between the docked ligand and the ligand as found in the crystal structure, using the programme LSQKAB, as provided in the CCP4 ${ }^{64}$ suite. If the root mean square deviation (RMSD) value between the real and the bestscored conformations is equal to or less than $2.0 \AA$ (representing the grid spacing used for the docking procedure), then the docking process was considered successful. ${ }^{65}$ In this case the docking procedure was first validated by re-docking the extracted co-crystallised ligand of human estrogen receptor$\alpha(\mathrm{ER} \alpha)$ (2-phenyl-1-[4-(2-piperidin-1-yl-ethoxy)-phenyl]-1,2,3,4tetrahydro-isoquinolin-6-ol) into the prepared target protein to be used for docking. The RMSD between the docked conformation, as generated by the docking algorithm and the native co-crystallised ligand conformation was found to be $0.12 \AA$, which was well within the 2 A grid spacing used in the docking procedure, indicating that the docking method to be used was reliable and valid. Furthermore, the interactions between the docked ligand and the prepared target receptor mimicked those observed in the crystal structure of the same.

Docking procedure. Docking studies were performed using the programme Surflex-Dock (SFXC) ${ }^{62}$ as provided by Sybyl-X 2.1. The X-ray crystallographic structures of human estrogen receptor- $\alpha(\mathrm{ER} \alpha)$ complexed with an antagonist 2-phenyl-1-[4-(2piperidin-1-yl-ethoxy)-phenyl]-1,2,3,4-tetrahydro-isoquinolin-6-ol (PDB code-1UOM, $2.28 \AA$ resolution) ${ }^{45}$ was retrieved from the Protein Data Bank. The protein structure was prepared for docking using the Biopolymer Structure Preparation Tool with the implemented default settings provided in the SYBYL programme suite. Hydrogens were added to the protein structures in idealised geometries and an overall energy minimisation of each protein was performed using the MMFF94 force field, employing a conjugate gradient algorithm ${ }^{66}$ with a convergence criterion of 
$0.5 \mathrm{kcal} \mathrm{mol}^{-1} \mathrm{~A}$ and up to 5000 iterations. Finally, before the docking run, all water molecules were removed and the ligand 2-phenyl-1-[4-(2-piperidin-1-yl-ethoxy)-phenyl]-1,2,3,4-tetrahydroisoquinolin-6-ol was extracted from the coordinate file of the ER $\alpha$ (PDB-1UOM). The protomol, representing the ligand binding groove, was generated using a ligand directed method, which allows the docking of ligands into predefined sites, as defined by occupancy of any co-crystallised ligand at the site of interest.

The Surflex-X docking algorithm docks a given ligand to a receptor using a flexible ligand and a semi-flexible receptor; in this case the peptides were allowed to be fully flexible while the receptor was semi-flexible. This approach allows for optimisation of potentially favourable molecular interactions, such as those defined by hydrogen bond and van der Waal forces. The docking results yield a docking score, which takes into consideration entropic, polar, hydrophobic, repulsive and desolvation factors. Here, the docking scores were expressed in $-\log _{10}\left(K_{\mathrm{d}}\right)$ units to represent binding affinities, where $K_{\mathrm{d}}$ is the dissociation constant. The free energy of binding of the ligand to the protein was extrapolated from eqn (1).

$$
\text { Free energy of binding }=R T \log _{\mathrm{e}} K_{\mathrm{d}}
$$

The docking results were visualised using the programme PyMOL $^{67,68}$ and the molecular interactions of the docked ligands were analysed by the programme CONTACTS, as provided in the CCP4 suite of programmes. ${ }^{64,69,70}$ Potential hydrogen bonds were assigned if the distance between two electronegative atoms was less than $3.3 \AA$, whereas any separation greater than $3.3 \AA$, but less than $4.5 \AA$, was considered a van der Waal interaction.

$\mathbf{E R} \boldsymbol{\alpha}$ antagonist assay. ER $\alpha$ reporter cells consisting of an $\mathrm{ER} \alpha$-responsive promoter gene functionally linked to the luciferase gene were defrosted and seeded into a 96-well plate and these cells were immediately dosed with the test compounds at different concentrations (10-0.1 $\mu \mathrm{M})$ and with $17 \beta$ estradiol (3.2 $\mathrm{nM}, \mathrm{EC}_{75}$ concentration) according to the manufacturer's protocol. After $24 \mathrm{~h}$ incubation in the presence of the test compound or solvent (DMSO), the cell viability of these treated/untreated reporter cells was measured to eliminate false positives using the fluorescence-based live cell multiplex (LCM) assay. The fluorescence from the live cells was measured using the plate reader with the filter combination of [485 $\mathrm{nm}$ ex|535 $\mathrm{nm} \mathrm{em}]$. Following this, fold reduction in the luciferase intensity, which is the measure of the antagonist activity was measured by using a luminometer (TECAN) according to the manufacturer's protocol. The data are expressed as the fold reduction as compared to the control. The mean of three experiments and the standard error is reported.

PathScan sandwich immunoassay. The PathScan Intracellular Signalling array kit was used for the simultaneous detection of 18 significant and well-characterised cellular proteins and signalling nodes that were phosphorylated or cleaved at the specific residues.

(a) Preparation of cell lysate. MCF-7 and MCF-7/DX cells $(8 \times$ $10^{4}$ cell per $\left.\mathrm{mL}\right)$ and MDA-MB-231 cells $\left(4 \times 10^{4}\right.$ cells per $\left.\mathrm{mL}\right)$

were seeded into 24 well plates ( $2 \mathrm{~mL}$ per well) and incubated for $24 \mathrm{~h}$. After $24 \mathrm{~h}$, the cells were treated with the test compounds at $10 \mu \mathrm{M}$ concentration for $24 \mathrm{~h}$. Following this $24 \mathrm{~h}$ exposure, the cells were washed with ice-cold $1 \times$ phosphatebuffered saline and lysed in $1 \times$ cell lysis buffer provided (phosphotase and protease inhibitors added). These lysates were quantified using the BCA protein assay.

(b) Assay procedure. The array blocking buffer was added to each well of the glass slide provided and incubated for $15 \mathrm{~min}$ at room temperature. Subsequently, the cell lysate, diluted to $0.3 \mathrm{mg} \mathrm{mL} \mathrm{m}^{-1}$ in array diluents, was added to each well and incubated for $2 \mathrm{~h}$ at room temperature. Subsequent to washing, the detection antibody cocktail was added to each well and incubated for $1 \mathrm{~h}$ at room temperature. Horseradish peroxidase (HRP)-linked streptavidin was added to each well and incubated for $30 \mathrm{~min}$ at room temperature. The slide was then covered with LumiGLO/peroxide reagent (Cell Signaling Technology) and exposed to film for 2-30 s. The image was captured by a digital imaging system, ImageQuant LAS 4000 (GE Healthcare).

Apoptosis detection assay. Apoptosis in MCF-7 and MDA-MB231 cells was assayed by annexin $\mathrm{V}$ and propidium iodide (PI) costaining using an Annexin-V-FITC staining kit according to the manufacturer's instruction. $1 \times 10^{6}$ MCF-7 and MDA-MB-231 cells were plated into a 6 well plate $\left(3.4 \times 10^{5}\right.$ cells per $\mathrm{mL}, 3$ $\mathrm{mL}$ per well). After $24 \mathrm{~h}$ incubation, cells were treated without and with test compounds (at their $\mathrm{IC}_{50}$ concentration) for $24 \mathrm{~h}$. Cells were harvested using Accutase ${ }^{\mathrm{TM}}$ cell detachment solution ( $1 \mathrm{~mL}$ per well) for $5 \mathrm{~min}$ at $37^{\circ} \mathrm{C}$. Accutase was inactivated by addition of complete medium $(2 \mathrm{~mL})$. Cells were collected by centrifugation at $100 \times g$ and the pellet was washed twice with cold PBS and then resuspended in $1 \mathrm{~mL}$ of annexin-binding buffer. $100 \mu \mathrm{L}$ of the cell suspension was transferred to $1.5 \mathrm{~mL}$ Eppendorf tube and $5 \mu \mathrm{L}$ of FITC-conjugated annexin $\mathrm{V}$ and $5 \mu \mathrm{L}$ of PI was added and incubated in dark for $15 \mathrm{~min}$ at room temperature. After 15 min incubation $400 \mu \mathrm{L}$ of annexin binding buffer was added to the cells and the fluorescence was measured using BD accuri ${ }^{\mathrm{TM}}$ instrument flow cytometry. The instrument was set for FL1 (annexin V-FITC) vs. FL3 (PI) bivariant analysis. Data from 10000 cells per sample was collected and dot plots of FL1 vs. FL3 were generated. The quadrants were set based on the population of healthy, unstained cells in untreated samples compared to cells treated with a known apoptotic inducer camptothecin $(5 \mu \mathrm{M})$ for $24 \mathrm{~h}$. BD CSampler ${ }^{\mathrm{TM}}$ software was used to calculate the percentage of the cells in the respective quadrants. The experiment was performed in triplicate.

\section{Conflict of interest}

The authors declare no competing financial interest.

\section{Abbreviations}

DMSO

DCM

EtOAc
Dimethylsulfoxide

Dichloromethane

Ethylacetate 
MTT

3-(4,5-Dimethylthiazol-2-yl)-2,5-diphenyltetrazolium bromide

NMR Nuclear magnetic resonance

IR Infrared

FTMS Fourier transform mass spectroscopy

ESI Electron spray ionisation

ERK1/2 Extracellular signal-regulated kinase

mTOR Mammalian target of rapamycin

PARP Poly(ADP-ribose) polymerase

AMPK $\alpha \quad 5^{\prime}$-Adenosine monophosphate-activated protein kinase

p53 Phosphoprotein53

GSK-3 $\beta \quad$ Glycogen synthase kinase-3 $\beta$

Bad Bcl-2-associated death promoter

PRAS40 Proline-rich Akt substrate of $40 \mathrm{kDa}$

PI3K Phosphatidylinositol-4,5-bisphosphate-3-kinase

MMFF94 Merck molecular force field 94

\section{Acknowledgements}

Financial support to DR from the Felix trust is gratefully acknowledged. We thank Amit Kumar Rajora for his help with the sample preparation for microarray experiments. We also thank the University of Reading for the provision of the Chemical Analysis Facility and Dr Philip Dash, University of Reading, UK for providing MDA-MB-231 cells. We gratefully acknowledge NCI, USA for accepting and screening our compounds against 60 cell lines [NSC reference numbers 783090 (15f) and 783091 (16f)].

\section{References}

1 A. L. Harvey, R. Edrada-Ebel and R. J. Quinn, Nat. Rev. Drug Discovery, 2015, 14, 111-129.

2 L. Ouyang, Y. Luo, M. Tian, S.-Y. Zhang, R. Lu, J.-H. Wang, R. Kasimu and X. Li, Cell Proliferation, 2014, 47, 506-515.

3 W. Ren, Z. Qiao, H. Wang, L. Zhu and L. Zhang, Med. Res. Rev., 2003, 23, 519-534.

4 P. Batra and A. K. Sharma, 3 Biotech, 2013, 3, 439-459.

5 J. Carini, F. Klamt and V. Linck, RSC Adv., 2014, 4, 31313144.

6 A. K. Verma and R. Pratap, Nat. Prod. Rep., 2010, 27, 15711593.

7 R. S. Keri, S. Budagumpi, R. K. Pai and R. G. Balakrishna, Eur. J. Med. Chem., 2014, 78, 340-374.

8 A. Gaspar, M. J. Matos, J. Garrido, E. Uriarte and F. Borges, Chem. Rev., 2014, 114, 4960-4992.

9 C. Kanadaswami, L. T. Lee, P. P. H. Lee, J. J. Hwang, F. C. Ke, Y. T. Huang and M. T. Lee, In Vivo, 2005, 19, 895-910.

10 D. Ravishankar, A. K. Rajora, F. Greco and H. M. I. Osborn, Int. J. Biochem. Cell Biol., 2013, 45, 2821-2831.

11 S. Kawaii, Y. Tomono, E. Katase, K. Ogawa and M. Yano, Biosci., Biotechnol., Biochem., 1999, 63, 896-899.

12 A. M. Senderowicz, Invest. New Drugs, 1999, 17, 313-320.
13 S. Burdette-Radoux, R. G. Tozer, R. C. Lohmann, I. Quirt, D. S. Ernst, W. Walsh, N. Wainman, A. D. Colevas and E. A. Eisenhauer, Invest. New Drugs, 2004, 22, 315-322.

14 J. A. Jones, A. S. Rupert, M. Poi, M. A. Phelps, L. Andritsos, R. Baiocchi, D. M. Benson, K. A. Blum, B. Christian, J. Flynn, S. Penza, P. Porcu, M. R. Grever and J. C. Byrd, Am. J. Hematol., 2014, 89, 19-24.

15 C. Loguercio and D. Festi, World J. Gastroenterol., 2011, 17, 2288-2301.

16 D. Ferry, A. Smith and J. Malkhandi, Clin. Cancer Res., 1996, 659-668.

17 P. J. Mulholland, D. R. Ferry, D. Anderson, S. A. Hussain, A. M. Young, J. E. Cook, E. Hodgkin, L. W. Seymour and D. J. Kerr, Ann. Oncol., 2001, 12, 245-248.

18 S. Kawa II, Y. Tomono, E. Katase, K. Ogawa and M. Yano, Biosci., Biotechnol., Biochem., 2014, 63, 896-899.

19 J. Yáñez, V. Vicente, M. Alcaraz, J. Castillo, O. BenaventeGarcía, M. Canteras and J. A. L. Teruel, Nutr. Cancer, 2004, 49, 191-199.

20 J. A. Manthey and N. Guthrie, J. Agric. Food Chem., 2002, 50, 5837-5843.

21 P. Parajuli, N. Joshee, A. M. Rimando, S. Mittal and A. K. Yadav, Planta Med., 2009, 75, 41-48.

22 M. Lopez-Lazaro and M. Akiyama, Curr. Med. Chem.: AntiCancer Agents, 2002, 2, 691-714.

23 M. López-Lázaro, M. Gálvez, C. Martín-Cordero and M. J. Ayuso, Stud. Nat. Prod. Chem., 2002, 27, 891-932.

24 J. F. W. McOmie, M. L. Watts and D. E. West, Tetrahedron, 1968, 24, 2289-2292.

25 W. Baker, J. Chem. Soc., 1933, 1381-1389.

26 M. P. Cava and M. I. Levinson, Tetrahedron, 1985, 41, 50615087.

27 J. Allan and R. Robinson, J. Chem. Soc., 1926, 129, 2334-2336.

28 D. Ravishankar, K. A. Watson, S. Y. Boateng, R. J. Green, F. Greco and H. M. I. Osborn, Eur. J. Med. Chem., 2015, 97, 259-274.

29 I. L. Martins, C. Charneira, V. Gandin, J. L. Ferreira da Silva, G. C. Justino, J. P. Telo, A. J. S. C. Vieira, C. Marzano and A. M. M. Antunes, J. Med. Chem., 2015, 58, 4250-4265.

30 J. G. Topliss, J. Med. Chem., 1972, 15, 1006-1011.

31 P. F. Devitt, A. Timoney and M. A. Vickars, J. Org. Chem., 1961, 26, 4941-4944.

32 C. Pouget, F. Lauthier, A. Simon, C. Fagnere, J. P. Basly, C. Delage and A. J. Chulia, Bioorg. Med. Chem. Lett., 2001, 11, 3095-3097.

33 N. Yao, C. Y. Chen, C. Y. Wu, K. Motonishi, H. J. Kung and K. S. Lam, J. Med. Chem., 2011, 54, 4339-4349.

34 K. Sak, Pharmacogn. Rev., 2014, 8, 122-146.

35 M. A. Indap, R. Susarla, L. Motiwale and K. V. K. Rao, Indian J. Pharm. Sci., 2006, 68, 465-469.

36 S. Yadegarynia, A. Pham, A. Ng, D. Nguyen, T. Lialiutska, A. Bortolazzo, V. Sivryuk, M. Bremer and J. B. White, Nat. Prod. Commun., 2012, 7, 1295-1304.

37 E. Mechetner, A. Kyshtoobayeva, S. Zonis, H. Kim, R. Stroup, R. Garcia, R. J. Parker and J. P. Fruehauf, Clin. Cancer Res., 1998, 4, 389-398. 
38 J. B. Daskiewicz, F. Depeint, L. Viornery, C. Bayet, G. ComteSarrazin, G. Comte, J. M. Gee, I. T. Johnson, K. Ndjoko, K. Hostettmann and D. Barron, J. Med. Chem., 2005, 48, 2790-2804.

39 I. N. Sergeev, C.-T. Ho, S. Li, J. Colby and S. Dushenkov, Mol. Nutr. Food Res., 2007, 51, 1478-1484.

40 T. Walle, Int. J. Mol. Sci., 2009, 10, 5002-5019.

41 T. Hirano, M. Gotoh and K. Oka, Life Sci., 1994, 55, 10611069.

42 M. Lacroix and G. Leclercq, Breast Cancer Res. Treat., 2004, 83, 249-289.

43 N. Sharma, M. Dobhal, Y. Joshi and M. Chahar, Pharmacogn. Rev., 2011, 5, 1.

44 S. Kumar and A. K. Pandey, Sci. World J., 2013, 2013.

45 J. Renaud, S. F. Bischoff, T. Buhl, P. Floersheim, B. Fournier, C. Halleux, J. Kallen, H. Keller, J.-M. Schlaeppi and W. Stark, J. Med. Chem., 2003, 46, 2945-2957.

46 T. Akama, Y. Shida, T. Sugaya, H. Ishida, K. Gomi and M. Kasai, J. Med. Chem., 1996, 39, 3461-3469.

47 G. V. Chaitanya, A. J. Steven and P. P. Babu, Cell Commun. Signaling, 2010, 8, 31.

48 L. M. Mooney, K. A. Al-Sakkaf, B. L. Brown and P. R. M. Dobson, Br. J. Cancer, 2002, 87, 909-917.

49 M. Olivier, R. Eeles, M. Hollstein, M. A. Khan, C. C. Harris and P. Hainaut, Hum. Mutat., 2002, 19, 607-614.

50 L. Hui, Y. Zheng, Y. Yan, J. Bargonetti and D. A. Foster, Oncogene, 2006, 25, 7305-7310.

51 A. L. Gartel, C. Feliciano and A. L. Tyner, Oncol. Res., 2003, 13, 405-408.

52 M. Hsiao, J. Low, E. Dorn, D. Ku, P. Pattengale, J. Yeargin and M. Haas, Am. J. Pathol., 1994, 145, 702-714.

53 P. A. J. Muller, P. T. Caswell, B. Doyle, M. P. Iwanicki, E. H. Tan, S. Karim, N. Lukashchuk, D. A. Gillespie, R. L. Ludwig, P. Gosselin, A. Cromer, J. S. Brugge,
O. J. Sansom, J. C. Norman and K. H. Vousden, Cell, 2009, 139, 1327-1341.

54 H.-Y. Lin, A. Shih, F. B. Davis, H.-Y. Tang, L. J. Martino, J. A. Bennett and P. J. Davis, J. Urol., 2002, 168, 748-755.

55 H. Y. Lin, H. Y. Tang, F. B. Davis and P. J. Davis, Ann. N. Y. Acad. Sci., 2011, 1215, 79-88.

56 A. Shih, S. Zhang, H. J. Cao, S. Boswell, Y.-H. Wu, H.-Y. Tang, M. R. Lennartz, F. B. Davis, P. J. Davis and H.-Y. Lin, Mol. Cancer Ther., 2004, 3, 1355-1364.

57 M. C. Willingham, J. Histochem. Cytochem., 1999, 47, 11011110.

58 K. Emoto, N. Toyama-Sorimachi, H. Karasuyama, K. Inoue and M. Umeda, Exp. Cell Res., 1997, 232, 430-434.

59 R. H. Shoemaker, Nat. Rev. Cancer, 2006, 6, 813-823.

60 V. Vichai and K. Kirtikara, Nat. Protoc., 2006, 1, 1112-1116.

61 T. Mosmann, J. Immunol. Methods, 1983, 65, 55-63.

62 A. N. Jain, J. Med. Chem., 2003, 46, 499-511.

63 A. N. Jain, J. Comput.-Aided Mol. Des., 2007, 21, 281-306.

64 Collaborative Computational Project, Number 4, The CCP4 Suite: Programs for Protein Crystallography, Acta Crystallogr., Sect. D: Biol. Crystallogr., 1994, 50, 760-763.

65 R. Wang, Y. Lu and S. Wang, J. Med. Chem., 2003, 46, 22872303.

66 M. J. D. Powell, Math. Program., 1977, 12, 241-254.

67 W. DeLano, CCP4 Newsl, Protein Crystallography, 40, 2002.

68 D. Seeliger and B. L. De Groot, J. Comput.-Aided Mol. Des., 2010, 24, 417-422.

69 K. Cowtan, P. Emsley and K. S. Wilson, Acta Crystallogr., Sect. D: Biol. Crystallogr., 2011, 67, 233-234.

70 M. D. Winn, C. C. Ballard, K. D. Cowtan, E. J. Dodson, P. Emsley, P. R. Evans, R. M. Keegan, E. B. Krissinel, A. G. W. Leslie, A. McCoy, S. J. McNicholas, G. N. Murshudov, N. S. Pannu, E. A. Potterton, H. R. Powell, R. J. Read, A. Vagin and K. S. Wilson, Acta Crystallogr., Sect. D: Biol. Crystallogr., 2011, 67, 235-242. 